\title{
Communal Feast Slametan: \\ Belief System, Ritual, and the Ideal of Javanese Society
}

\author{
Ahmad Hakam \\ Universitas Negeri Jakarta \\ ahmad-hakam@unj.ac.id \\ Naskah diterima: 22-9-2016, direvisi:3-1-201, disetujui:27-1-2017
}

\begin{abstract}
Abstrak
Artikel ini fokus pada keyakinan keagamaan dan ritual slametan masyarakat Muslim Jawa. Ritual slametan dianggap penting di kalangan komunitas masyarakat Jawa dan telah dipandang sebagai ritual sinkretis dari Islam dan tradisi Kejawen Hindu, serta sudah mentradisi di masyarakat. Ritual slametan dalam artikel ini dianalisis terkait dengan idealisme keutuhan dan harmoni sebagai standar dan acuan indikator bahwa kehidupan harus teratur dan slamet atau 'tak terjadi apa-apa'. Tidak ada dikotomi kultur Jawa dan ajaran agama Islam yang dianut karena kedua hal ini terlihat berjalan beriringan. Artikel ini berargumen bahwa slametan adalah ritual utama masyarakat muslim Jawa yang merefleksikan dan menyimbolkan kepercayaan agama, prinsip slamet, yang berarti sebuah harapan bahwa dalam hidup tidak terjadi apa-apa atau musibah, hidup bersama secara sosial dengan rukun, dan menyadari tentang pentingnya menghormati keberadaan orang lain. Prinsip dan idealisme ini pada akhirnya mengandung unsur kesakralan tradisi dan religius yang berpengaruh pada dinamika saling mempengaruhi antara perilaku individu dan sosial.
\end{abstract}

Kata kunci: slametan, budaya Jawa, masyarakat muslim

\begin{abstract}
This paper focuses on the Javanese Muslims religious belief and its ritual, slametan, which is prevalently performed in Java. This ritual is of great significance to the Javanese Muslim community, and is counted as syncretistic ritual of Islamic and the Javanese traditions. The ritual is though analysed in relation to the society ideal of unity and harmony as the standard set for the indicator that the life of people is in order and in a slamet condition or 'nothing happens'. This paper argues that this ceremony is the main ritual among Javanese Muslims which to a large extent reflects and symbolises the religious belief, slamet principle of the people living together, and having strong awareness of others. This ideal in the end conceives some element of sacredness which has the influence on the relationship between individual and social behaviour.
\end{abstract}

Keywords: slametan, Javanese cultures, muslim societies

\section{Introduction}

Java is the most densely inhabited island situated in the southern part of Indonesian archipelago and is renowned for its diverse cultures and beliefs. It after the independence from the Dutch is administratively divided into four provinces - DKI Jakarta, West Java, Central Java along with Yogyakarta, and East Java - where the language spoken is 
Javanese with varied dialects and accents. An exception is to the melting-pot capital city, Jakarta, where Indonesian or Bahasa Indonesia, formal and colloquial, is spoken and also the West Java where the people speak Sundanese which is a different language from Javanese (Vickers, 2005, p. 1) (Koentjaraningrat, p. 2). The majority of the people embrace Islam or they at least identify themselves as Muslims and it is quite likely that Islam is also a religion of Java. Thus, being Javanese also means being Muslim. Unlike the Javanese Christians, they, when asked, will say it if they are not Muslims (Koenjtaraningrat R. M., 1985, pp. 316-317). There is a ritual which is of immense importance to the people, called slametan and anthropologists in general agree that it is the core ritual in Javanese (Muslim) society (Beatty A. , 1999, p. 27). This ritual has been discussed by many authors such as Geertz (1960), Woodward (1989), and Beatty (1999) who conducted their research mainly in central or east Java areas.

The slametan feast is one of the most widely-practiced rituals in $\mathrm{Java}^{1}$ (Lapidus, 2012; Robinson, 2008; Budijanto, 2009; Kim, 2007). The word slametan comes from the Javanese slamet and most probably Arabic salam as well. It means well being, peace, safety, health, goodness and in essence it refers to the state of stasis or simply 'nothing happens' to one or to people (Geertz C. , 1991, pp. 264-267). Being slamet implies that one is safe, in the sense that people can avoid difficulties or troubles derived from natural or supernatural condition. The purpose of slametan is not to quest for joy, financial richness, best healthiness, but simply to prevent unwanted events from happening, nothing will make a person unwell physically or mentally, not to become ill or sad because of bad things that may happen. Slametan is performed for one of the occasions of birth, marriage, death, house moving, child circumcision, political meeting, opening a factory, and other important moments in life (Geertz C. , 1960, pp. 11-13)

The slametan feast is usually held by a host in the living room or other rooms large enough to accommodate guests, after sunset and the evening prayer time. Mats are spread on the floor of one's house and gradually people come and place themselves as convenient as they wish and form circular or semi circular gathering with food already prepared in the centre, usually consists of beautifully made rice cones, with other dishes such as meat,

\footnotetext{
${ }^{1}$ It is performed among Javanese communities in various regions in Java.
} 
eggs, vegetables, fruits and drinks; tea and mineral water and the burn of incense ${ }^{2}$. The invitees are men - wearing sarongs and proper dress and black velvet or white hats - from the neighbourhood, close friends, and some relatives (Beatty A., 1999, pp. 11-13). When everyone is seated, the host makes a little formal speech thanking the guests' attendance and the reason of the slametan gathering. The official speaker or whoever chosen starts a short praise or salawat to the Prophet Muhammad followed by the recitation of sura Alfatiha and certain Arabic prayer for welfare, and audience say amin after each line of the supplication (Beatty A. , 1999, pp. 30-33). When the chants finish each person eats the meals together and the host is there encouraging once or more to try all the dishes before they leave. Some foods remain uneaten and they may wrap and take them home to eat together with their family (Beatty A. , 1999, pp. 30-33). This all the way marks the completion and the end of the ritual of slametan, which seems to be animistic Islamic Hindu combinations (Hilmy, 1999). ${ }^{3}$

It is still a debate whether slametan is more Islamic, animistic-Hindu, or syncretistic (Hilmy, 1999). Yet, this paper will stress not on the nature of the ritual but endeavour to regard this as a core ritual among Javanese Muslims as part of the society, i.e. this ritual is practiced by the people who are being Javanese as well as being Muslims ${ }^{4}$ (Koenjtaraningrat R. M., 1985, hal. 16-317; Möller \& André, p. 1). The discussion therefore will focus on the religious beliefs and the main ritual ${ }^{5}$ (Beatty A. , 1999, p. 27), slametan, in relation to the society ideal of unity and harmony in which people are living together and hoping nothing either naturally or supernaturally disturb or cause badness.

The questions are, therefore, how do the Javanese society conceive the religious belief and the ritual, and what is the ideal of the society as reflected and symbolised in the widely-practiced slametan? The findings suggest that the members of the society should

${ }^{2}$ More modern slametans don't require burn of incense and specific kind of food; the host rather offers some common heavy meals and deserts. Also, participants don't necessarily have to wear certain dress commonly used for prayers and formal rituals.

${ }^{3}$ Hilmy discusses the understanding of slametan through the perspective of ritual based on textual (religious) and contextual (socio-cultural) analysis arguing both Geertz from socio-cultural viewpoint and Woodward from Islamic theological basis in 'Islam and Javanese Acculturation: Textual and Contextual Analysis of the Slametan Ritual'.

${ }^{4}$ Koentjaraningrat says that most Javanese identify themselves as Muslim although some may not perform seriously the principles such as prayer and avoiding eating pork or having willingness to go to Mecca for pilgrimage but many of them do fast during Ramadan. See. Koenjtaraningrat, Javanese Culture, p. 16-317, However, recent observation by Möller (2006: 1) says that Javanese people are consistent in fivetime prayers a day and Ramadan fasting. So it is widely relative to the individuals and community situation in certain area. But in general the majority of Javanese are Muslims and claim as Muslims unless they are Christian, Catholic, Hindu or Buddhist they will say so.

${ }^{5}$ Anthropologists in general agree that slametan is the core ritual in Javanese (Muslim) society. 
conform to certain attitude in social interaction and relationship within the community. Not to create disharmony or unsafeness is thus something valued and is followed by concrete actions such as not to hurt others, not to cause people to lose face in public, keeping selfemotion inside and prioritising communal interest over one's own (Mulder N. , 1998, p. 65). The ignorance of this unity and harmony aspiration will be considered not good and not giving respect to people and the community (Mulder N. , 1998, p. 62). It is thus assumed that the society idyllic is reflected in Javanese Muslim individuals and their behaviour and this state is maintained through the ritual of the sacred slametan (Beatty, 1999; Geertz, 1960; Woodward,1989 and Mulder, 1998). The discussion will then start with the Javanese beliefs and ethics, slametan ritual and communal values, and the individuals' behaviour in social context, and finally the conclusion.

\section{Methodology}

This study first explores the literature on Muslim society in general and specifically the Javanese Muslim who inhabit Java island, particularly of those living in the central and east Java. This two provinces share the same language, although with various dialects, and cultural heritage of the ancient kingdoms, whereas the west Java has their own tradition of Sundanese culture.

The study is qualitative and does not involve numbers for the basis of analysis (Ritchie \& Lewis, 2003, p. 3). The theories from the literature are discussed before the synthesis of the idea is constructed and aimed to fill the gap in the current research on the issue. The slametan is almost always part of the issues examined in studying the Javanese Muslim society. There is a number of researches in some regions in Java, such as the wellknown account on the Javanese society by Geertz (1965), Kim (2007), Budijanto (2009), Robinson (2998), Beatty (1999), Möller (2006), and Lapidus (2012). Many of these scholars conducted their field study in central and east Java and stayed for duration of time to observe and gather their data before they make conclusion. This article uses the findings as the sources for analysis and to finally draw conclusion.

It is a library-research project and supported by direct observation in the field during my visit to one of the region in central Java, the western and south part of Java, which is stretching from Purwokerto to Kebumen regions. The observation was particularly conducted in Gumelar Lor village. The first observation was carried out in 2010 and the second one was conducted in 2016. Some observations were also carried out in 
Jabodetabek area, in Jakarta and its surrounding areas. I was part of the ceremony and very much seen as the insider, not merely a researcher of the phenomenon. The data from the literature and observation is then compared and contrasted to what has been found in the literature and used for analysis and drawing conclusion.

\section{Belief and Ethics}

Javanese people had been in the crossfire of many religious ideas which were animistic, Hindu-Buddhist teachings-practices and combining magic, mysticism, veneration of powerful souls, spirit cults, and the worship of holy places (Mulder N. , 1998, p. 14). Also according to Koentjaraningrat (Koenjtaraningrat, p. 324), Javanese culture and religion comprise of great variation of beliefs, concepts, views, and values such as the belief in God or Allah the Almighty, in Muhammad the prophet, in other prophets, in saints, the cosmogonical concept of creation, and the cosmological view of nature and the world, eschatology, the belief in deities, the concept of death and the afterlife, in ancestor spirits, in guardian spirits, in ghosts, spooks and giants, and the concept of magical power. After the advent of Islam in Java, the changes in their belief is not leading to becoming homogenous Javanese Muslims but rather allowing them to be diverse in interpreting Islam and its teaching along with their previous or existing beliefs.

The non homogeneity of Javanese Muslims can be construed either hierarchically or through socio-cultural backgrounds as proposed by Geertz (1960), stating that Javanese people are categorised into three; abangan, santri, and priyayi. Abangan are peasant folk who have stronger flavour of animistic and Hinduistic traditions and spirit beliefs. Meanwhile, the Santri are more concerned with the basic Islamic teachings and rituals such as prayers, the fast, the pilgrimage, charitable activities, and political Islamic organisations and also their typical occupation as traders (Geertz C. , 1960, pp. 5-6). This nevertheless does not mean that they do not practice some ritual which is considered by some scholars as syncretistic, i.e. slametan.

The last group is priyayi who were originally the descendants of aristocrats or royal family in ancient Javanese kingdoms and became the government officials under the colony of Dutch. This elite people hold their traditions of respecting court etiquette, complex sense of arts including drama, music, dance, Hindu-Buddhist mysticism, and linguistic aspects such as poetry and use of different language level and addressing between the social ranks as for example the subordinates can speak the same language 
between them but have to use second or first grade language to their superiors (Geertz C. , 1960, p. 254). In other words the division of the Javanese people can also be described as three different places for their daily activities; village, market, and government bureaucracy (Geertz C. , 1960, pp. 3-5).

Despite the variety of the Javanese beliefs and social structure, in the sense of ethics they tend to have common social philosophy which is unity and harmony (Mulder N. , 1998, p. 59). The mystical ideal of unity and harmony constitutes the relationship between man and society as it is modelled in the relationship between man and God as the creator which is honoured and positioned in high place and it is also the belief of the Javanese Muslim where the unity and harmony which lead to order is the main purpose of living. Mulder adds that the idea of unity implies orderliness and the harmony might be imperilled by personal desires, ambitions, and passions. So to sacrifice self for the sake of social harmony will be appreciated and highly valued. In other words, asserts Mulder, 'a person should give himself up to the community rather than try to impose his will' (Mulder N. , 1998, pp. 61-62)

In addition to the individual and society relationship, Javanese ethics underlies the inner and outer elements which is dependent each other, as it is between self and others (Beatty A. , 1999, pp. 178-179). 'One cannot be truly slamet unless circumstances - which include the well-being of others - allow it. Javanese people say that if one neglects the general welfare one's own slamet is diminished' (Beatty A. , 1999, pp. 178-179). It may seems simple but, says Beatty, each individual spend great effort on keeping self awareness of others which is called make rumangsa, feeling or awareness of self and other and it is needed as the basis of social harmony or rukun (Beatty A. , 1999, pp. 178-179). It is therefore can be inferred that this kind of relationship is of great importance in Javanese society which concern with the total world order and its unity and harmony ${ }^{6}$ (Yumarma, 1996, p. 117).

Mulder further argues that in Javanese society, such relationship forms order of society as it is a part of the total cosmic order (Mulder N. , 1998, pp. 79-80). This kejawen

${ }^{6}$ From the Javanese's conception of the world, Yumarma (1996: 117) points out 'important characteristics which align with the concept of harmony, keselarasan: 1) The unification of the world as a whole; 2) the connection of events to the world; and 3) the reciprocal relationship between one's image of the world and the adaptation pragmatic values to obtain a silent, peaceful heart and a balanced mind. All these points, taken together, constitute a harmonious expression of reality and human life without rigorous distinction between religion, society, the world and culture.' 
(Javanism) ethic leads to the consideration to pursue budaya ('culture': knowledge and wisdom) in order to recognise oneself existence in society and life; 'one will also know the ethic and task that belong to one's place. People should live attuned to it all (Mulder N. , 1998, pp. 79-80). In their phenomenal existence they should respect the order of society, honour elders and superiors, and be considerate of inferiors by taking the measure of oneself'.' From this explanation it is clear that individuals are demanded to care about harmonious relationships, although it is only on the surface or on the outer expression visible by others as to stay away from all open conflict. In doing so, knowledge and self mastery must be developed from within or from their batin (Mulder N. , 1998, pp. 79-80; Yumarma, 1996, p. 118) which in general brings the idea of Javanese mysticism kebatinan (Geertz C. , 1960, p. 309; Mulder N. , 1998, p. 29 and 71; Koentjaraningrat, Javanese Culture, p. 398 and 402). The concept of inner and outer and relationship between individual and society is thus assumed to be manifested in the slametan ritual which requires the community members' attendance and their awareness of others' condition of goodness through the ceremony.

\section{Slametan and Being in Goodness or 'Nothing Happens'}

Slametan gathering does not only involve the host's friends, neighbours, fellow workers, and relatives, but also unseen participants such as local spirits and dead ancestors (Geertz C. , 1960, p. 14) as the idea behind the ritual is to achieve goodness or "nothing happens' to anyone and avoid disturbances either from natural or supernatural beings. In brief, there are two dimensions - among people and people with the local spirits - of interaction of the Javanese people in which they believe in spirit and supernatural beings which are also living together around them and also present with them in slametan. The goal is orderliness and people's well being and it is expected that none is going to alter it. They therefore again are pursuing the total goodness and harmony of living and it includes the cosmos orderliness so that whoever live in it together try not to cause badness to each other. As mentioned earlier, the core ritual is meant to sustain, maintain, or promote order. It is slametan, a communal religious meal in which the all beings participate for their harmony and blessings from God.

The participants of a slametan ceremony, according to Geertz, cross the threshold into a sphere where aggressive feelings toward others disappear and where the absence of emotional disturbances prevails (Geertz C. , 1960, p. 14). 'Their intention is to attain the 
state of slamet, which Koentjaraningrat once described it as 'a state in which events run their fixed course smoothly and nothing untoward happens to anyone.' (Mulder N. , 1998, p. 85). It is not only enhancing the sense of social solidarity among the participants of the ceremony, but also calming down and making peace with local spirits (Koentjaraningrat, p. 349) and all profane emotions should be absent to develop self mastery of respecting others and the harmony during the slametan.

According to Koentjaraningrat (1985: 350), not all slametan ceremonies are necessarily religious or such a sacred as claimed by Geertz. He divided slametan, quoting Bachtiar (1973) into two, sacred and secular. Its sacredness can be identified by the emotion which exists in the minds of the host and the family members so they can also transfer the feelings and sacredness to the participants during the ceremonial occasion, especially when chanting $\mathrm{zdikir}^{7}$ is being performed. The latter, secular slametan, are characterised by the least or absence of sacred emotion in the minds of the host and his family, as well as among other participants in the ceremonial act, even though it also involves a religious official who chant the zdikir and $d u^{\prime} a$ or supplication for blessings over the people and the food (Koenjtaraningrat, p. 350).

Such invocations are held at all of life's important occasions which are conditioned to be more sacred in especially the death and the life cycle ceremony which takes place after seven days, one hundred days and one year, haul, from the day someone passed away. The ceremonies at forty days of women's pregnancy and the birth and the seventh day of the infant age also tend to give more emotions and sacredness since it is related to the strong expectation of the host and participants for being safe and nothing happens to anyone. This demonstrates the slamet quest, through the communal celebrations, to ensure undisturbed continuity. It is also performed when well-being and equilibrium have been affected. The secular or least sacred slametan is in the occasions of moving to a new house, changing names, starting long journey, promotion in workplace, academic graduation, and anniversaries of club or institutions (Koentjaraningrat, p. 51). Mulder says that in theory, all participants enjoy the same ritual status, each person is contributing equally to the spiritual power of the event. 'The slametan, therefore serves to express the harmonious community known as rukun, which is the prerequisite for effectively calling for the blessing of gods, spirits and ancestors' (Mulder N. , 1998, p. 86).

\footnotetext{
${ }^{7}$ It can be qur'anic verses recitation, supplication or du'a for goodness and hoping the dead ancestors to be in peace.
} 
The rukun situation in Javanese society life also involves individual understanding from within and concern with fellow-feeling or rumangsa. As it is said by Beatty that rasa (feeling-intuition) concerns the inner life, personal salvation and empathy which are all motivated by a sense of mutual benefit. If one is invited to a slametan he or she would feel the matter concerned by the host and be willing to exchange hopes for slamet, i.e. participants have duwérumangsa, or feeling aware. The shape of the feast ritual is hence tightly bound in an ideal social-spiritual circumstance in which people set aside their differences and get together in one place (Beatty A. , 1999, pp. 178-179)

\section{Individuals' Behaviour in Social Interaction}

Having the concept of togetherness and strong awareness of others, the life situation in Javanese society is not likely leaving much room for bare open individual expression which according to Mulder, it might slightly isolates people from each other (Mulder N. , 1998, pp. 64-65). 'Personal expression [which could hurt other's feeling] - especially the show of emotions - is impolite, embarrassing, and a violation of the privacy of others. Social life should be shielded from individual intrusions by safeguarding polite form, hierarchy, and harmony.' (Mulder N. , 1998, pp. 64-65) This seems, says Mulder, to keep individual and society a distance from each other, but in other sense it might not simply mean creating gap for the sake of harmony but the Javanese worldview encourage indirectness in social relationship. It gives impression that people are advised to hide behind formality and politeness and which imply good etiquette while it is ambiguous (Mulder N. , 1998, pp. 64-65). One tends to say yes all the time because agreement seems to be polite and saying no is considered impolite. (Mulder N. , 1998, pp. 64-65)

Other practical terms that correspond to politeness are 'do not irritate the other', 'be careful not to hurt the other's feeling', 'do not insult the other but show respect for his position', 'do not cause trouble to others' and any suggestions similar to them (Mulder N. , 1998, p. 65). In addition, politeness and good manners also include not having frontal disagreement to someone especially in public which is considered rude. Self sensitivity to others is also valued as one should not lose his face in public or which can affect one's position and image. This kind of relationship according to Muller may cause restrictions in life but people can actually be free with their own feeling inside. On the other hand, this attitude is still in correlation with the mystic inner life awareness and it practically persuade self perception towards others, to adapt and not to fight as to bring the 
harmonious order in social life. The harmony can be a mark that the people are given blessings from God (Mulder N. , 1998, p. 69) and as in slametan people gather without competing each other and not to cause any disruption to each other, stressing the continuance of being in a good state.

There some changes, continuation, and variation in the slametan ceremony. Some differences and similarities can also be noticed across regions. In general, the basic elements and procession look quite consistent through time. The slametan I observed in central Java consists of the same components as reported by the scholars before. It was started by preparation of the slametan ritual after the common important event happened, such as death, birth, or marriage. Women tend to be more active, in preparing the meals, but it does not mean that the male members of the family are strictly not involved. The previous research from gender perspective might not apply in this case, since male members of the family also took part in preparing the food for the participants in the slametan. After the guests come, the master of ceremony would begins saying Islamic greeting and introduction and then a kiyai or an ustadz will lead the steps in the ritual. People will just usually sit and listen to the slametan leader and repeat the chanting and prayer after him in the name of particular purpose of the slametan, be it for the safety and blessing of one's birth, death, marriage, moving to a new house, and so on.

Since most part of central and east Java is rural, it does not mean that slametan is typical rural ritual. It is also widely practiced in many urban areas as confirmed by Woodward (2014:117), his research in Yogyakarta. My experience also indicate that slametan is practiced in even a more urban and megacity like Jakarta, although slightly varied in the procession. The city slametan is more of an invitation of the host to pray together on important events in life like those in the villages in Java. Congregational praying is more considered by God than one family alone. So, in the event of birth, marriage, death, it is common to hold a slametan or with another term for it, tahlilan, one of the chanting in slametan is tahlil which is the shahadah. The slametan in rural and urban areas nowadays no longer involve awareness with the unseen beings except God and the deceased relatives. The kiyai or ustadz who leads the slametan ritual will begin with reciting alfatihah, the salawat or reciting the biography of the Prophet Muhammad, pray for the deceased relatives of the host, pray for the smoothness of one of the important life events, and closing the ceremony by the Islamic $d u^{\prime} a$ in Arabic. Meals are sometimes 
enjoyed in the venue or taken away after the host and family members or any relatives or neighbours who help the ceremony distribute them to each participant.

The principle of slamet in ideal sense and the general etiquettes of the Muslims in Java interact as a combination of hoping to be saved from bad things and doing nothing bad to other fellow community members as well. The feeling of sacredness in the ritual in the form of congregational recitation of particular Islamic chanting such as the sura AlFatiha and sura Yasin from the Quran, salawatan, religious sermon, and specific du'a for specific purpose according to the important life event which is the most significant to the host who invite the people to pray together and pray in the name of the family of the host. In return, and for cultural norm, the host provide foods and meals for the participant to thank them for their willingness and sincerity to participate in the slametan. Conversation between participants usually takes place during the sermon by the ustadz or after all the ritual and procession of slametan finishes.

\section{Conclusion}

Slametan is a communal feast and it incorporates different layers of the total life and the world. Individual's goodness and community to the broader scope of unity and harmony ideal - which also implies the good relationship with God and receiving blessings - to a great extent are realised in the slametan ritual. At some points it seems intertwining between the slamet and unity and harmony. To be slamet means not only for one but for the entire society and it is the type of unity and harmony which cannot be achieved without the slamet. Slamet is the main goal and it is the ideal which is always expected in life. To be slamet is to have nothing happens or troubling or ga ana apa apa. To be slamet is the utmost ideal state in life and slametan ceremony is performed and maintained as the fear of possible misfortune drives them and overpowers their action to hold the slametan ritual. On the other hand, people in general should also be in slamet state so the gathering in one sense is crucial for them to know the members of the community are slamet and they do invoke for each other's safeness, slamet, 'nothing-happenness'.

One should be in such condition while realising very well that others are also slamet. This concept and ideal leads to the nothing-happens or no-conflict-happens between individuals or between an individual and society. It is confirmed by Beatty when he says 'the slametan as a ritual which has elements of sacred symbolises the Javanese society ideal of unity and harmony. The slametan represents the ideal; but in everyday life, too, 
one is expected to share in the joys and sorrows of one's neighbours 'left and right"' (Beatty, 1999:179). In addition, slametan also demonstrate the desire to be safe in an unruly world. They do not aim at a better life, now or in the future, but rather at the maintenance of order and the constraining of danger. It also appears, however, that humans play an active role in maintaining this order and can influence its course, well-ordered social relationships being a means to and a condition for promoting the state of slamet (Mulder N., 1998, p. 86).

The state of slamet, a condition which is the framework and the social realisation and unselfishness is illustrated in the Javanese culture through manifestation in the slametan as the symbol of communal equality and harmony since there is no differentiation should be exposed where everyone is sitting together on the floor and sharing the foods and indirect information of one's goodness. On the other hand, the society might not be present as such in individual. The ideal is framed within the inner from the outer and the division of sacred and profane in slametan is not as clear as in the totemic community where Durkheim conducted his research (Headley \& C, 2004, p. 514). However, in Javanese society, the individual actions and behaviour towards others and society also do not demonstrate independence of expressing open serious remark or disagreement potent to disturb harmony, which might be considered endangering the slamet-ness of people. This also cannot be regarded as merely a social force but the individual common values should also be viewed as each of them constitute and contribute to a society which is not homogenous.

In practicing one of the Ramadan traweh prayer, for example, two Muslim communities in Java differ in the amount of the prayer cycle, raka'at, between eight or twenty (Möller, 2006). This principle is reasonably potent to create confrontation by legitimising one and negating other based on religious grounds such as scripture, tradition and Islamic jurisprudence. Nevertheless, rarely happens or almost no open or public conflict in Javanese society. The reason of the people intermingling and no ruthless frictions among the different group of Muslims who differ in their understanding is, Möller asserts, due to cultural smoothness of the Javanese people - Muslims and Non-Muslims, in handling their difference - who to a great extent underline rukun, harmony and slamet, tranquillity (Möller, 2006, p. 16). 


\section{References:}

Budijanto, Bambang. (2009). Development in Rural Indonesia. Oxford: Regnum.

Durkheim, Emile. (1915). The Elementary Forms of Religious Life, trans. J.W. Swain, London.

Geertz, Clifford. (1960). Religion of Java. Chicago: The Chicago University Press.

Beatty, Andrew. (1999) Varieties of Javanese Religion. Cambridge: Cambridge University Press.

Geertz, Clifford. (1991). 'Religious Belief and Economic Behaviour in a Central Javanese Town: Some Preliminary Considerations' in Hamiltion, ed. Critical Assessment Max Weber volume 1 pp. 259-301. Routledge. Available at http://books.google.com/books?id=p84OAAAAQAAJ\&pg=PA264\&dq=slametan+sa cred\&lr= accessed on 16 March 2009 at 22.17.

Headley, Stephen C. (2004). Durga's Mosque: Cosmology, Conversion and Community in Central Javanese Islam. Singapore: ISEAS.

Hilmy, Masdar. (1999). 'Islam and Javanese Acculturation: Textual and Contextual Analysis of the Slametan Ritual' (Master Thesis, McGill University). Available online at http://www.collectionscanada.gc.ca/obj/s4/f2/dsk2/ftp03/MQ50521.pdf accessed on 19 March 2009 at 21.26.

Kim, Hyung-Jun. (2007). Reformist Muslims in A Yogyakarta Village: The Islamic Transformation of Contemporary Socio-Religious Life. Canberra: ANU E Press.

Koentjaraningrat, R. M. (1985). Javanese Culture. Singapore: Oxford University Press.

Lapidus, Ira. (2012). Islamic Societies to the Nineteenth Century: A Global History. Cambridge: Cambridge University Press.

Möller, André. (2006). 'Islam and Traweh Prayers in Java: Unity, Diversity and Cultural Smoothness' anpere e-journal for the study of anthropology of religion. Available at http://www.anpere.net/2006/7.pdf accessed on16 March 2009 at 23.30.

Mulder, Niels (1998). Mysticism in Java: Ideology in Indonesia. Amsterdam: The Pepin Press.

Robinson, Kathryn May. (2008). Gender, Islam, and Demeocracy in Indonesia. ASAA Women in Asia Series. London: Routledge.

Ritchie, J. and Jane Lewis. (2003). Qualitative Research Practice: A Guide for Social Science Students and Researchers. London: SAGE Publications.

Vickers, Adrian. (2005). A History of Modern Indonesia. Cambridge: Cambridge University Press. 
Woodward, Mark. (2011). Java, Indonesia and Islam. London: Springer.

Yumarma, Andreas. (1996). Unity in Diversity: A Philosophical and Ethical Study of the Javanese Concept of Keselarasan. Rome: Pontifical Gregorian University. 